\title{
YIELD AND QUALITY OF YELLOW PASSION FRUITS ACCORDING TO ORGANIC FERTILIZATION AND ALTERNATIVE PHYTOSANITARY MANAGEMENT
}

\author{
Anália L. V. Pacheco으, Karina S. Borges ${ }^{2}$, Gilberto B. de Freitas ${ }^{3}$, Gerival Vieira ${ }^{3}$
}

\begin{abstract}
Growing yellow passion fruit is a profitable activity, with a high demand for labor, and it is practiced especially by family-based farmers. However, the production cost is rather high and a significant part of this cost is associated with the expenses related to fertilization and phytosanitary treatments necessary for obtaining satisfactory yields and high commercial quality fruit. Therefore, the objective of this study was to evaluate the effect of using organic compound in fertilization of plants and alternative products in phytosanitary treatments (Bordeaux mixture, Neem oil and lime sulfur mixture) on the yield and quality of fruits. Yellow passion fruits were submitted to three types of fertilization (mineral, organic and organic-mineral) and two types of phytosanitary treatment ('conventional' and 'alternative'). This experiment evaluated fruit yield ( $\mathrm{kg} / \mathrm{plant}$ ) and fruit quality by using the following evaluations: seedless pulp yield, soluble solids content (SS), titratable acidity (TA), SS/TA ratio and vitamin C content. The different types of fertilization did not interfere in fruit yield, however, plants under conventional phytosanitary treatment displayed higher yields. The SS content and TA of the fruits were influenced only by fertilization, where plants that received mineral and organic-mineral fertilization produced fruit with higher contents of SS and TA. Pulp yield, SS/TA ratio and vitamin C content were not influenced by any of the evaluated factors. Regarding cultivation of passion fruit, it is possible to substitute some mineral fertilizers for organic fertilizers with no negative effects on the fruit yield or quality. However, the substitution of pesticides for alternative products compromises fruit yield.
\end{abstract}

Keywords: alternative products, mineral fertilization, organic-mineral fertilization, Passiflora edulis Sims f. flavicarpa Deg.

\section{PRODUÇÃO E QUALIDADE DE FRUTOS DE MARACUJAZEIRO AMARELO, EM FUNÇÃO DE ADUBAÇÃO ORGÂNICA E TRATAMENTO FITOSSANITÁRIO ALTERNATIVO}

\begin{abstract}
RESUMO - O cultivo do maracujazeiro amarelo é uma atividade rentável, de alta demanda de mão de obra, sendo praticada especialmente por agricultores familiares. Contudo, o custo de produção é bastante elevado, e uma parte significativa desse custo está associada aos gastos relativos às adubações e tratamentos fitossanitários indispensáveis para obtenção de produtividades satisfatórias e frutos de alta qualidade comercial. Assim sendo, o objetivo do presente estudo foi avaliar o efeito do uso de composto orgânico nas adubações das plantas e de produtos alternativos nos tratamentos fitossanitários (mistura de Bordeaux, óleo de Neem e mistura de cal e enxofre), na produção e qualidade dos frutos. Plantas de maracujá amarelo foram submetidas a três tipos de adubação (mineral, orgânica e organomineral) e dois tipos de tratamento fitossanitário ('convencional' e 'alternativo'). Avaliou-se a produção de frutos ( $\mathrm{kg} /$ planta) e a qualidade dos mesmos mediante as seguintes avaliações: rendimento de polpa sem semente, teor de sólidos solúveis (SS), acidez titulável (AT), relação
\end{abstract}

\footnotetext{
${ }^{1}$ 1Engenheira-Agrônoma, Doutoranda. Departamento de Fitotecnia, Universidade Federal de Viçosa, Avenida Peter Henry Rolfs, s/n, 36570-000, Viçosa, Minas Gerais, Brasil. (31) 3899-1326. analia.pacheco@ufv.br

${ }^{2}$ Biológa, Doutoranda. Departamento de Agricultura, Universidade Federal de Lavras, Campus Universitário, Caixa Postal 3037,37200-000- Lavras, Minas Gerais, Brasil. karina.schulz.borges@gmail.com

${ }^{3}$ Engenheiros-Agrônomos, DS. Departamento de Fitotecnia, Universidade Federal de Viçosa, Av. Peter Henry Rolfs, s/n, 36.570-000 - Viçosa, Minas Gerais, Brasil.bernardo@ufv.br, gerival@ufv.br
} 


\begin{abstract}
SS/AT e vitamina C. Os diferentes tipos de adubação não interferiram na produção de frutos, contudo, plantas submetidas ao tratamento fitossanitário convencional apresentaram-se mais produtivas. O teor de SS e AT dos frutos foram influenciados apenas pela adubação, sendo que plantas que receberam adubação mineral e organomineral produziram frutos com maiores teores de SS e AT. O rendimento de polpa, a relação SS/ AT e o teor de vitamina C não foram influenciados por nenhum dos fatores estudados. Conclui-se que, no cultivo do maracujazeiro amarelo, é possível substituir parte dos adubos minerais por adubos orgânicos, sem comprometer a produção e qualidade dos frutos. Contudo, a substituição dos agrotóxicos por produtos alternativos compromete a produção de frutos.
\end{abstract}

Palavras-chave: adubação mineral, adubação organomineral, Passiflora edulis Sims $f$. flavicarpa Deg,

\section{INTRODUCTION}

Growing yellow passion fruit is a profitable activity, with high demand for labor, practiced especially by family-based farmers. Each planted hectare generates from three to four direct jobs and takes seven to eight people in the various links in the production chain (Meletti, 2011). A study conducted in sixteen municipalities in the interior of São Paulo state found that the average size of passion fruit commercial crops was 0.58 ha (Furlaneto et al., 2011).

In addition, this crop also provides rapid economic return and the revenue is distributed most of the year (Meletti et al., 2010). However, the production cost is quite high, reaching $R \$ 37,512.00$ and $R \$ 53,474.00$ per hectare of dryland (no irrigation) and irrigated crops, respectively (AGRIANUAL, 2016), values that are incompatible with the investment capacity of most farmers. A significant part of the crop production cost is associated with expenses related to fertilization and phytosanitary treatments necessary to obtain satisfactory yields and high commercial quality fruit.

This species is demanding of nutrients, and fertilization of plants may affect both production and the external characteristics of the fruit, such as appearance, size, roughness of the skin, and internal characteristics such as percentage of juice, soluble solids content, acid index and the presence of physiological disorders. Such effects vary according to the studied species, amount and types of fertilizers used (Weston \& Barth, 1997; Mattheis \& Fellman, 1999; Aular et al., 2014).

The crop also presents serious phytosanitary issues, especially in areas with high relative air humidity, as the region of Zona da Mata (Forest Zone) in the state of Minas Gerais, and if these issues are not managed properly, they severely affect yield and fruit quality.
Initially, the passion fruit was grown for at least three consecutive years, however, over the past decade, in many regions, growing passion fruit has become an annual crop, especially because of the PWV (Passion fruit Woodeness Virus) (Sampaio et al., 2008). In addition, phytosanitary treatments have been intensified and raised the cost of crop production.

Therefore, many farmers, concerned about the high cost of production of the crop, have sought to use available resources on the farm (wood for construction of trellis and organic fertilizers) and low-cost and of easy preparation alternative products, such as the Bordeaux and lime-sulfur mixtures, replacing agro-chemicals used for phytosanitary management. Alternative products have also been used by agroecological and organic farmers. However, reducing the crop production cost by replacing commercial inputs with available alternative products or easily prepared on the farm may not result in greater profitability for the grower since this procedure may affect both production and fruit quality. Therefore, the objective of this study was to evaluate the effect of using organic compound for fertilizing passion plants and alternative products on the phytosanitary treatments, production and fruit quality.

\section{MATERIALAND METHODS}

The experiment was carried out at the Fruit Sector of the Federal University of Viçosa, in Viçosa, state of Minas Gerais, from September 2009 to May 2011. The orchard was set with seedlings of the yellow passion fruit variety (Passiflora edulis Sims f. flavicarpa Deg) FB - 200 from VIVEIROS FLORA BRASIL (Flora Brasil Nursery), spaced by $3.0 \times 3.0$ meters $(\mathrm{m})$, by conducting the plants on vertical trellising system with a wire $2.0 \mathrm{~m}$ above the ground. No artificial pollination nor irrigation (dryland farming) were carried out. The soil in the experimental area presented at the orchard setting, the following characteristics: $\mathrm{pH}$ 
$\left(\mathrm{H}_{2} \mathrm{O}\right)=6.2 ; \mathrm{P}=13.3 \mathrm{mg} \cdot \mathrm{dm}^{-3} ; \mathrm{K}=45.0 \mathrm{mg} \cdot \mathrm{dm}^{-3} ; \mathrm{Ca}^{2+}=$ $3.7 \mathrm{cmol}_{\mathrm{c}} \cdot \mathrm{dm}^{-3} ; \mathrm{Mg}^{2+}=1.0 \mathrm{cmol}_{\mathrm{c}} \cdot \mathrm{dm}^{-3} ; \mathrm{Al}^{3+}=0.0$ $\mathrm{cmol}_{\mathrm{c}} \cdot \mathrm{dm}^{-3}$; and content of organic matter $(\mathrm{OM})=$ 1.6 dag. $\mathrm{kg}^{-1}$

The experiment was set up in September, 2009 in a split plot design with randomized blocks, three replicates and two plants per experimental unit. The plots received two types of phytosanitary treatments (conventional $\backslash$ agro-chemicals - AGC and alternative alternative products - AP) and the sub-plots received three types of fertilizers (mineral - MF; organic - OF and organic-mineral-OMF).

The planting holes were digged with dimensions of $0.40 \times 0.40 \times 0.40$ and received the following fertilizers: MF with 400 g.plant ${ }^{-1}$ of simple superphosphate and 12 1.plant ${ }^{-1}$ of organic compound (OC); OF with 400 g.plant ${ }^{-1}$ thermophosphate and 12 1.plant $^{-1}$ of OC; OMF with 200 g.plant $^{-1}$ of simple superphosphate, 200 g.plant ${ }^{1}$ of thermophosphate and 12 1.plant ${ }^{-1}$ of OC.

Top-dressing fertilization was split during the rainy season in the months of October $\backslash 2009$, December $\backslash 2009$ and February $\backslash 2010$, October $\backslash 2010$, December $\backslash 2010$ and February $\backslash 2011$ and the following amounts of fertilizers were applied in each season: MF with 100 g.plant ${ }^{1}$ of ammonium sulfate, 100 g.plant ${ }^{-1}$ of superphosphate and 100 g.plant ${ }^{-1} \mathrm{KCl}$; OF with 500 g.plant ${ }^{-1}$ of eucalyptus ash (EA) and 6.0 1.plant ${ }^{-1}$ of OC; OMF with 50 g.plant ${ }^{1}$ of ammonium sulfate, 50 g.plant ${ }^{-1}$ of simple superphosphate, 50 g.plant ${ }^{-1}$ of kCl, 3.0 1.plant ${ }^{-1}$ of OC and 250 g.plant ${ }^{-1}$ of EA.

The compound used in fertilizations presented the following characteristics: $\mathrm{pH}\left(\mathrm{H}_{2} \mathrm{O}\right)=7.13 ; \mathrm{N}=1.74 \%$; $\mathrm{P}=0.93 \% ; \mathrm{K}=1.37 \% ; \mathrm{Ca}^{2+}=2.46 \% ; \mathrm{Mg}^{2+}=0.55 \%$.

Phytosanitary treatments were the products presented in Table 1. The agro-chemicals were applied on the aerial part of the plants every 21 days and alternative products every 14 days, alternating Bordeaux mixture, Neem oil and lime sulfur mixture.
Fruit yield was evaluated (kg/plant) for two consecutive crops (out-of season and the main crop) and quality of the fruits of the main crop was evaluated by pulp yield (seedless), soluble solids content (SS), titratable acidity (TA), SS/TA ratio and vitamin $\mathrm{C}$ content.

Pulp yield was obtained by dividing the weight of the seedless pulp by the weight of the whole fruit multiplied by 100 in samples of 10 fruits per plot. The soluble solids content was determined using homogenized samples of the pulp through direct reading on portable refractometer, with a reading of 0 a $32^{\circ}$ Brix, according to the analytical standards of the Ial (2008). For determining the titratable acidity content, homogenized samples of $5 \mathrm{ml}$ of pulp were used. Three drops of phenolphthalein indicator $1 \%$ were added to each sample. After that, titration was carried out under stirring, with $\mathrm{NaOH} 0.1 \mathrm{~mol}^{-1} \mathrm{~L}^{-1}$ (Ial, 2008). The $\mathrm{SS} / \mathrm{TA}$ ratio was achieved through $\mathrm{SS} / \mathrm{TA}$ direct ratio. The vitamin $\mathrm{C}$ content was obtained by titration with Tillmans reagent (2.6-dichlorophenol - indophenol) according to analytical standards of the Ial (2008) and results expressed in $\mathrm{mg}$ of vitamin $\mathrm{C}$ per 100 grams of pulp.

Data collected from each evaluated characteristic were tabulated in an electronic spreadsheet and then analyzed using the statistical program ASSISTAT (Silva \& Azevedo, 2012) through the analysis of variance and the Tukey test $5 \%$.

\section{RESULTS AND DISCUSSION}

In the first production cycle (out-season crop), plants produced an average of $4.30 \mathrm{~kg}$ of fruits per plant. At this stage, the phytosanitary treatment affected fruit yield, although neither the effect of fertilization nor the interaction between the factors had been observed (Table 2). Plants treated with conventional plant phytosanitary management yielded $6.59 \mathrm{~kg}$ of fruit, on average, while plants treated with the alternative

Table 1 - Products used for phytosanitary management: conventional $\backslash$ agro-chemicals (AGC), alternative products (AP), Folicur 200EC (FO), Lebaycid 500 (LE), spreader sticker (SS), Bordeaux mixture (BM), lime sulfur mixture (LS), Neem oil (NO)

\begin{tabular}{ccccccc}
\hline Phytosanitary management & FO & LE & SS & BM & LS & NO \\
\hline$(\mathrm{ml} / 1)$ & $(\mathrm{ml} / 1)$ & $(\mathrm{ml} / 1)$ & $(\%)$ & $(\%)$ & - & $(\%)$ \\
AGC & 1.0 & 1.0 & 0.5 & - & 1.0 & 1.0 \\
AP & - & - & 0.5 & 0.5 \\
\hline
\end{tabular}


phytosanitary management yielded $2.02 \mathrm{~kg}$ of fruit, on average (Table 3).

Low yield per plant that received alternative phytosanitary treatment is associated with lower efficiency of alternative products used to control pests and diseases, especially anthracnose. It was found in the plants of this treatment a high mortality rate of the pointers of tertiary branches, damaging the vegetative growth of plants and consequently the fruit yield since the passion plants produces fruit only in new branches, in full vegetative growth. This severe occurrence of anthracnose was due to the climatic conditions favorable to the development of the pathogen, that is, high moisture and high temperature (Figure 1). Under conditions of high air relative moisture and temperatures around 26 to $28^{\circ} \mathrm{C}$, anthracnose is a limiting factor of the crop, especially if rainfall is frequent and abundant (Ferrari, 2006).
Despite the low effectiveness of Bordeaux mixture and lime sulfur mixture in controlling anthracnose in passion fruit under the environmental conditions in which the experiment was carried out, Ming et al. (2012) reported the control of leaf diseases of sweet passion fruit in organic farming with lime sulfur mixture at $0.5 \%$ of concentration and Mezzalira et al. (2015) reported the fig rust control with Bordeaux mixture at $1.5 \%$. Ferreira et al. (2015) evaluated the effect of organic waste as an alternative measure to control fusarium in yellow passion fruit, and babaçu coconut waste at a concentration of $60 \mathrm{~g} \mathrm{~kg}^{-1}$ and cassava peels at $80 \mathrm{~g}$ $\mathrm{kg}^{-1}$ were efficient in controlling; however, eucalyptus residue did not affect the development of the disease. Cruz et al. (2015) tested the Neem oil at $4 \%$ efficiency and manipueira (a byproduct from cassava flour production) mixture at $10 \%$ on the control of Dione juno juno caterpillar on yellow passion fruit. Only

Table 2 - Analysis of Variance with the F test, coefficient of variation and overall mean of physical and chemical characteristics of yellow passion fruits (Passiflora edulis Sims f. flavicarpa Deg;) achieved by the combined effect of two phytosanitary management and three fertilizations. Viçosa - MG, 2016

\begin{tabular}{|c|c|c|c|c|c|c|c|}
\hline Variation Source & $\begin{array}{c}\text { OC } \\
(\mathrm{kg} / \text { planta })\end{array}$ & $\begin{array}{c}\mathrm{MC} \\
(\mathrm{kg} / \text { planta })\end{array}$ & $\begin{array}{l}\text { PY } \\
(\%)\end{array}$ & SS & TA & $\mathrm{SS} / \mathrm{TA}$ & VIT C \\
\hline Phytosanitary management (PM) & $358.43^{* *}$ & $16.20^{\mathrm{ns}}$ & $5.85^{\mathrm{ns}}$ & $0.36^{\mathrm{ns}}$ & $0.0013^{*}$ & $0.10^{\mathrm{ns}}$ & $0.97^{\text {ns }}$ \\
\hline Fertilization (F) & $0.23^{\mathrm{ns}}$ & $2.73^{\mathrm{ns}}$ & $0.64^{\mathrm{ns}}$ & $6.25^{*}$ & $6.44^{*}$ & $3.92^{\mathrm{ns}}$ & $0.61^{\mathrm{ns}}$ \\
\hline $\mathrm{PM} \times \mathrm{F}$ & $1.66^{\mathrm{ns}}$ & $2.38^{\mathrm{ns}}$ & $2.13^{\mathrm{ns}}$ & $4.96^{*}$ & $0.99^{\text {ns }}$ & $0.15^{\mathrm{ns}}$ & $2.10^{\text {ns }}$ \\
\hline CV - PM (\%) & 11.87 & 34.44 & 8.41 & 9.50 & 26.21 & 3.07 & 13.19 \\
\hline$C V-F(\%)$ & 30.57 & 25.23 & 9.78 & 4.36 & 12.99 & 27.68 & 21.69 \\
\hline Overall mean & 4.30 & 12.93 & 41.19 & 14,30 & 4.85 & 12.15 & 15.60 \\
\hline
\end{tabular}

${ }_{\text {ns }}$ non-significant, ${ }^{*}$ and ${ }^{* *}$ significant at 5 and at $1 \%$ of probability, respectively. OC - out-of-season crop; MC - main crop; PY - pulp yield; SS - soluble solids; AT - titratable acidity; SS/AT ratio; VIT C - vitamin C; CV - coefficient of variation.

Table 3 - Mean values of physical and chemical characteristics of yellow passion fruits (Passiflora edulis Sims f. flavicarpa Deg) obtained by combined effect of fertilization and phytosanitary control. Viçosa - MG, 2016

\begin{tabular}{|c|c|c|c|c|c|c|c|}
\hline $\begin{array}{l}\text { Phytosanitary } \\
\text { management } \\
\text { and Fertilization }\end{array}$ & OC (kg/plant) & $\mathrm{MC}(\mathrm{kg} / \mathrm{plant})$ & PY (\%) & SS & TA & $\mathrm{SS} / \mathrm{TA}$ & VIT C \\
\hline AGC & $6.59 \mathrm{a}$ & $17.16 \mathrm{a}$ & $43.17 \mathrm{a}$ & $14.11 \mathrm{a}$ & $4.86 \mathrm{a}$ & $3.00 \mathrm{a}$ & $15.12 \mathrm{a}$ \\
\hline AP & $2.02 \mathrm{~b}$ & $8.70 \mathrm{a}$ & $39.22 \mathrm{a}$ & $14.50 \mathrm{a}$ & $4.84 \mathrm{a}$ & $3.14 \mathrm{a}$ & 16.08 \\
\hline LSD & 1.04 & 9.04 & 7.03 & 2.76 & 2.58 & 1.73 & 4.18 \\
\hline MF & $4.56 \mathrm{a}$ & $13.27 \mathrm{a}$ & $42.69 \mathrm{a}$ & $15.00 \mathrm{a}$ & $5.55 \mathrm{a}$ & $2.76 \mathrm{a}$ & 16.68 \\
\hline OF & $4.05 \mathrm{a}$ & $10.57 \mathrm{a}$ & $40.17 \mathrm{a}$ & $13.75 \mathrm{~b}$ & $4.26 \mathrm{~b}$ & $3.36 \mathrm{a}$ & $14.52 \mathrm{a}$ \\
\hline OMF & $4.30 \mathrm{a}$ & $14.94 \mathrm{a}$ & $40.72 \mathrm{a}$ & $14.16 \mathrm{ab}$ & $4.73 \mathrm{ab}$ & $3.09 \mathrm{a}$ & $15.60 \mathrm{a}$ \\
\hline LSD & 2.17 & 5.38 & 6.65 & 1.03 & 1.04 & 0.62 & 5.58 \\
\hline
\end{tabular}

Means followed by the same letter in the column are not different by Test of Tuckey at $5 \%$ of probability. AGC - conventional $\backslash$ agro-chemicals; AP - alternative product; LSD - least significant difference; MF - mineral fertilizer; OF - organic fertilizer; OMF - organic mineral fertilizer; OC - out-of-season crop; MC - main crop; PY - pulp yield; SS - soluble solids; TA - titratable acidity; SS/TA ratio; VIT C - vitamin C. 
manipueira mixture caused the death of $100 \%$ of the caterpillars, whereas the use of Neem oil was not effective at all in eliminating the plague.

In the second production cycle (main crop), plants yielded an average of $12.93 \mathrm{~kg}$ of fruit per plant, which is equivalent to an increase of over 300\% in relation to the out-of-season crop (Table 2). This increase in the yield between the first and second production cycle of the crop is expected in passion fruit (Meletti et al., 2005; Pimentel et al., 2008). There was no influence of any factor on the yield in the main crop. Nevertheless, plants receiving agro-chemicals as a way of phytosanitary management showed higher yield than those treated with alternative products (Table 3 ).

The average yield obtained in the out-of-season crop and in the main crop were 4.7 and $14.36 \mathrm{t} \mathrm{ha}^{-1}$, respectively. The average income of passion fruit in Brazil was $14.63 \mathrm{tha}^{-1}$, and the average in Minas Gerais was $16.29 \mathrm{tha}^{-1}$ (IBGE, 2013). The lack of pollination and irrigation certainly limited fruit yield by the plants in this study. Artificial pollination increases yield, mass, diameter and fruit length and percentage of pulp, reducing the thickness of the shell (Krause et al., 2012; Martins et al., 2014).

Pulp yield, SS/TA ratio and vitamin C content of the fruit were not affected by the evaluated factors, so little there was interaction between the factors for these parameters (Tables 2 and 3 ). The contents of soluble solids and titratable acidity of the fruits were influenced by fertilization (Table 2). Fruit from plants fertilized exclusively with organic compound showed SS content and TA lower than fruits from plants fertilized exclusively with mineral fertilizers. Fruit from plants treated with organic mineral fertilizer $(50 \%$ mineral fertilizer $+50 \%$ organic fertilization) showed intermediate levels of SS and TA, which is not statistically different from levels found in plant fruit under mineral fertilization (Table 3).

The only parameter that accused interaction between the type of phytosanitary treatment and fertilization was the SS content (Table 2), where plants that received the application of AP/MF and AP/OMF showed the same SS content of plants receiving application of AGC/ MF. The lower levels were found in plants that received the application of AP/OF and AGC/OMF (Table 4).

This reduction in the content of SS in fruits from plants under organic fertilization was not expected since

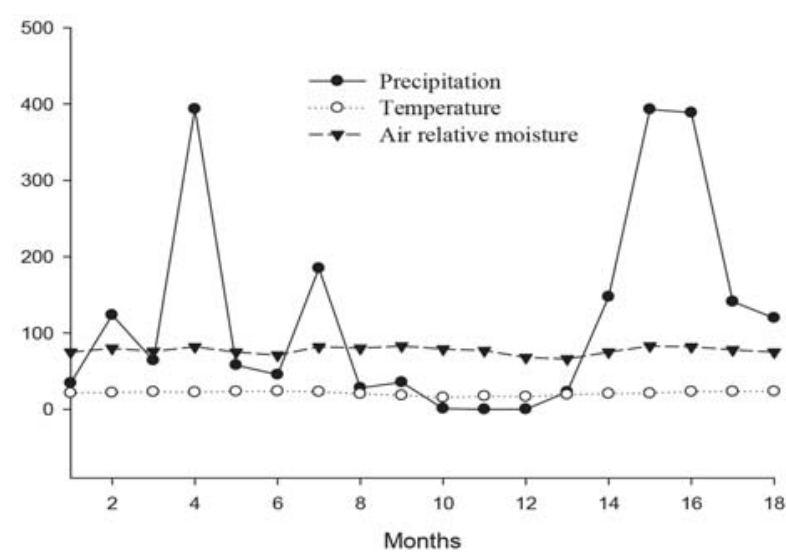

Figure 1 - Month average of rainfall, temperature and air relative moisture from September/2009 (month 1) to February/2011 (month 18). Source: Estação Climatológica Principal de Viçosa (UFV).

Table 4 - Unfolding of phytosanitary management (AGC and AP) and fertilization (MF; OF; OMF) interaction on soluble solid content (SS) of passion fruit (Passiflora edulis Sims f. flavicarpa Deg) obtained with the fertilization and phytosanitary control combined effect. Viçosa - MG, 2016

\begin{tabular}{lccc}
\hline & MF & OF & OMF \\
\hline AGC & $15.00 \mathrm{aA}$ & $14.00 \mathrm{aAB}$ & $13.33 \mathrm{aB}$ \\
AP & $15.00 \mathrm{aA}$ & $13.50 \mathrm{aB}$ & $15.00 \mathrm{aA}$ \\
\hline
\end{tabular}

Means followed by the same lower case letter in the column and upper case letter in the row are not difference by the test of Tuckey at $5 \%$ of probability. Least significant difference for columns is 2.1224 and 1.4546 for rows. MF - mineral fertilizer; OF - organic fertilizer; OMF - organic mineral fertilizer; AGC - conventional lagro-chemicals; AP - alternative product.

many studies, especially those related to plants under organic management, point to a rise in the levels of SS in fruit from plants under organic management (Damatto Junior et al., 2005, Sarmento et al., 2012), not only for passion fruit, but for other tropical fruits like bananas, where organic management was found to allow a higher mean value compared to conventional cultivation system for Silver-dwarf cultivar (Ribeiro et al., 2012). In addition, yellow passion fruits that received nitrogen fertilizer as urea (Venâncio et al., 2013), showed lower SS content than the fruits receiving OF and OMF in this study. The short period of organic fertilization in this study (18 months) and the lack of irrigation 
may have contributed to the lower response of plants to organic fertilization, that is, such conditions did not allow adequate mineralization of the organic compound, affecting the availability of nutrients for the plants (Carvalho et al., 2000; Silva et al., 2014.). According to Herencia et al. (2011), the crop has to be conducted for a few years under the same conditions in order to obtain representative and reliable results.

According to the Technical Regulation for the setting of identity and quality standards for passion fruit pulp, the minimum value of SS is $11^{\circ}$ Brix and $2.5 \%$ of TA (BRASIL, 2000). Thus, all treatments produced pulp with the quality required by law.

\section{CONCLUSIONS}

- The type of phytosanitary management affected fruit yield.

- Plants submitted to the alternative phytosanitary management yielded less fruit than plants under conventional phytosanitary management.

- The use of organic compound in plant fertilization affected fruit quality.

- Plants fertilized with organic compost exclusively produced fruits with lower contents of soluble solids and lower acidity.

- Organic-mineral fertilization (50\% mineral fertilization $+50 \%$ organic fertilization) did not affect yield or fruit quality.

- The substitution of mineral fertilizer for organic compound is viable in passion fruit crop.

\section{CITED LITERATURE}

\section{AGRIANUAL - ANUÁRIO DAAGRICULTURA BRASILEIRA. São Paulo, FNP. 2016. 472p.}

AUlAR, J.; CASARES, M.; NATALE, W. Mineral nutrition and fruit quality of pineapple and passion fruit. Revista Brasileira de Fruticultura, v.36, p.1046-1054, 2014.

BRASIL. Instrução Normativa $\mathrm{n}^{\circ} 01$, de 07 de janeiro de 2000. Regulamento técnico geral para fixação dos padrões de identidade e qualidade para polpas e sucos de frutas. DOU, 10/01/2000, Seção 1, p.259, 2000 .
CARVALHO, A.J.C.; MARTINS, D.P.; MONNERAT, P.H. et al. Nitrogen fertilization and irrigation depths in yellow passion fruit: I Yield and fruit quality. Pesquisa Agropecuária Brasileira, v.35, p.1101-1108, 2000.

CRUZ, M.P.; CRUZ, K.R.P.; ANDRADE JÚNIOR, M.R. et al. Utilização de defensivos alternativos no combate da lagarta na cultura do maracujazeiro amarelo (Passiflora edulis Sims f. flavicarpa Degener). Cadernos de Agroecologia, v.10, p.1-4, 2015.

DAMATTO JUNIOR, E.R.; LEONEL, S.; PEDROSO, C.J. Organic fertilization in fruit production and quality of sweet passion fruit.

Revista Brasileira de Fruticultura, v.27, p.188-190, 2005.

FERRARI, J.T. Aspectos fitossanitários do maracujazeiro. In: NOGUEIRA, E.M.C.; FERRARI, J.T. (Eds.) Aspectos fitossanitários do maracujazeiro. São Paulo: Instituto Biológico, 2006. 81 p.

FERREIRA, R.B.; RODRIGUES, A.A.C.; MORAES, F.H.R. et al. Resíduos orgânicos no controle de Fusarium oxysporum f. sp. passiflorae em maracujazeiro amarelo (Passiflora edulis $\mathrm{f}$. flavicarpa). Acta Biológica Colombiana, v.20, p.111-120, 2015.

FURLANETO, F.P.B.; MARTINS, N.A.; ESPERANCINI, M.S.T. et al. Custo de produção do maracujá-amarelo (Passiflora edulis). Revista Brasileira de Fruticultura, v.33, p.441-446, 2011.

HERENCIA, J.F.; GARCÁ-GALAVÍS, P.A.; DORADO, J.A.R. et al. Comparasion of nutricional quality of the crops grown in na organic and conventional fertilized soil. Scientia

Horticulturae, v.129, p.882-888, 2011.

IAL - Normas analíticas do Instituto Adolfo Lutz: Métodos químicos e físicos para análises de alimentos. 4 ed. São Paulo, IMESP. 2008. 1020p.

IBGE - INSTITUTO BRASILEIRO DE GEOGRAFIA E ESTATÍSTICA. Produção Agrícola Municipal - culturas temporárias e permanentes, Rio de Janeiro, v.40, p.1-102, 2013. 
KRAUSE, W.; NEVES, L.G.; VIANA, A.P. et al. Produtividade e qualidade de frutos de cultivares de maracujazeiro-amarelo com ou sem polinização artificial. Pesquisa agropecuária brasileira, v. 47, p.1737-1742, 2012.

MARTINS, M.R.; REIS, M.C.; ARAÚJO, J.R.G. et al. Tipos de polinização e pastejo de abelhas Xylocopa spp. na frutificação e qualidade dos frutos de maracujazeiro. Revista Caatinga, v.27, p.187-193, 2014.

MATTHEIS, J. P.; FELLMAN, J.K. Preharvest factors influencing flavor of fresh fruit and vegetables. Postharvest Biology and Technology, v.15, p.227-232, 1999.

MELETTI, L.M.M.; SOARES-SCOTT, M.D.; BERNACCI, L.C. Caracterização fenotípica de três seleções de maracujazeiro-roxo (Passiflora edulis

Sims). Revista Brasileira de

Fruticultura, v.27, p.268-272, 2005.

MELETTI, L.M.M.; OLIVEIRA, J.C.; RUGGIERO C. Maracujá. Jaboticabal: FUNEP. Série Frutas Nativas, p55, 2010.

MELETTI, L.M.M. Avanços na cultura do maracujá no Brasil. Revista Brasileira de Fruticultura, v.33, p.83-091, 2011.

MEZZALIRA, E.J.; PIVA, A.L.; NAVA, G.A. et al. Controle da ferrugem e da broca-dos-ramos da figueira com diferentes fungicidas e inseticidas. Revista Ceres, v.62, p.44-51, 2015.

MING, L.C.; MAIA-ALMEIDA, C.I.; MARQUES, M.O.M. et al. Eficiência da calda bordalesa e sulfocálcica em diferentes concentrações e idade da planta no controle de doenças foliares do maracujá-doce em cultivo orgânico. Journal of Biotechnology and Biodiversity, v.3, p.30-35, 2012.
PIMENTEL, L.D.; STENZEL, N.H.C.; CRUZ, C.D. et al. Seleção precoce de maracujazeiro pelo uso da correlação entre dados de produção mensal e anual. Pesquisa Agropecuária Brasileira, v.43, p.1303-1309, 2008.

RIBEIRO, L.R.; OLIVEIRA, L.M.; SILVA, S.O. et al. Caracterização física e química de bananas produzidas em sistemas de cultivo convencional e orgânico. Revista Brasileira de Fruticultura, v.34, p.774-782, 2012.

SAMPAIO, A.C.; SCUDELLER, N.; FUMIS, T.F. et al. Manejo cultural do maracujazeiro-amarelo em ciclo anual visando à convivência com o vírus do endurecimento dos frutos: um estudo de caso. Revista Brasileira de Fruticultura, v.30, p.343-347, 2008.

SARMENTO, J.D.A.; MORAIS, P.L.D.; ALMEIDA, M.L.B. et al. Qualidade pós-colheita de banana submetida ao cultivo orgânico e convencional. Revista Brasileira de Produtos Agroindustriais, v.14, p.85-93, 2012.

SILVA, F.A.Z.; AZEVEDO, C.A.V. Programa Assistat - versão 7.6 beta. Campina Grande- PB, Brasil, 2012.

SILVA, V.B.; SILVA, A.P.; DIAS, B.O. et al. Decomposition and mineralization of $\mathrm{N}, \mathrm{P}$ and $\mathrm{K}$ of cattle manure and poultry litter isolated or mixed.

Revista Brasileira de Ciência do Solo, v.38, p.1537-1546, 2014.

UNIVERSIDADE FEDERAL DE VIÇOSA - UFV. Departamento de Engenharia Agrícola. Estação Climatológica Principal de Viçosa. Boletim meteorológico 2016.

VENÂNCIO, J.B.; RODRIGUES, E.T.; SILVEIRA, M.V. et al. Produção, qualidade dos frutos e teores de nitrogênio foliar em maracujazeiro-amarelo sob adubação nitrogenada. Científica, v.41, p.11-20, 2013.

WESTON, L.A.; BARTH, M.M. Preharvest factors affecting postharvest quality of vegetable. HortScience, v.32, p.812-816, 1997.

Recebido para publicação em 17/4/2017 e aprovado em 11/9/2017. 